\title{
Neotyphodium interactions with a native grass are driven by endophyte haplotype
}

\author{
L. J. MORSE, S. H. FAETH and T.A. DAY \\ Arizona State University, School of Life Sciences, P.O. Box 874501, Tempe, AZ 85287-4501 \\ lauracucci@gmail.com
}

\begin{abstract}
We examined the effect of endophyte infection, endophyte and host plant maternal genotype on traditional growth parameters. We also measured leaf water potential, leaf rolling, and stomatal density to provide explanations for differences in biomass production and relative growth rates. Our general findings show that Neotyphodium infection, Neotyphodium haplotype and its interaction with host maternal genotype influence Arizona fescue growth, and biomass production. Endophyte haplotype and its interaction with host maternal genotype is the most critical and consistent factor in influencing growth and physiological outcomes. Endophyte-host interactions are likely to be enormously complex because of the genetic and environmental variation that exists in natural populations. The outcome of these interactions in natural grass-endophyte systems is exceedingly difficult to predict based simply on the presence or absence of the endophyte.
\end{abstract}

Keywords: growth rate, haplotype, leaf rolling, plant biomass, water potential, stomatal density

\section{Introduction}

Increasing evidence suggests that the outcome of the interaction between Neotyphodium endophyte and environmental factors depends on the genotype of the host grass and the haplotype of the endophyte (systemic endophytes are haploid) (Saikkonen et al. 2004; Müller \& Kraus 2005). This dependency is even evident in agronomic grasses, where genetic variation of both host and endophyte are limited due to bottleneck effects and selective breeding.

Far less is known about the influence of Neotyphodium infections on wild populations of native grasses than on agronomic grasses (e.g. Faeth 2002). Festuca arizonica Vasey (Arizona fescue) is a native perennial bunchgrass, that is widespread in semi-arid ponderosa pine (Pinus ponderosa)/grassland communities above $2000 \mathrm{~m}$ elevation in the southwest USA (Kearney \& Peebles 1960). Neotyphodium infection frequencies in wild populations of Arizona fescue are usually high. Surveys show the frequency of infected plants in Arizona fescue populations range from 50-100\% (Schulthess \& Faeth 1998; Saikkonen et al. 1999). Despite high frequencies, however, the infection by asexual Neotyphodium does not appear to benefit the host, as predicted for Neotyphodium symbionts of tall fescue and ryegrass (Wilkinson \& Schardl 1997).

Genetic variation in Neotyphodium endophytes also potentially influences interaction outcomes. Different Neotyphodium strains that have been intentionally manipulated or transferred to agronomic tall fescue may alter growth and physiological properties of the host (e.g. Assuero et al. 2000, 2002). To our knowledge, there have been no tests of how endophyte haplotype in conjunction with host genotype and environmental factors, alters host growth and biomass production, gas exchange, and water relations in native grasses infected with Neotyphodium.

We assessed the relative performance in terms of growth and biomass production of uninfected (E-) and Neotyphodium infected
$(\mathrm{E}+)$ plants with two endophyte haplotypes within four maternal genotypes of Arizona fescue. We measured traditional growth analysis parameters, including relative growth rates, aboveand below-ground biomass and below-ground:above-ground biomass ratios. We also measured water potential, leaf rolling, and stomatal density to provide explanations for differences in biomass production and relative growth rates. Our purpose here is to incorporate not just infection status but also variation in endophyte haplotypes within hosts and the environment to determine how these factors interact to influence host growth.

\section{Methods}

\section{The host plant - Festuca arizonica}

Festuca arizonica Vasey (Arizona fescue) is a native perennial bunchgrass that is widespread in semi-arid ponderosa pine (Pinus ponderosa)/grassland communities above $2000 \mathrm{~m}$ elevation in the southwest USA (Kearney \& Peebles 1960)). Neotyphodium infection frequencies in wild populations of Arizona fescue are usually high.

\section{The endophyte - Neotyphodium}

Arizona fescue harbours at least three distinct forms of Neotyphodium, each likely a unique species (Sullivan \& Faeth 2004). Two of the four maternal plants use in our experiments (MD 1 and MD 49) harboured one non-hybrid endophyte haplotype (termed H1) and the other two maternal plants (MD 44 and MD 46) harboured another non-hybrid endophyte haplotype (termed H2). Haplotypes of the experimental plants were confirmed by microsatellite DNA analyses of multiple loci (Sullivan \& Faeth 2004).

\section{Seed sources}

To test the effect of infection, host maternal genotype and endophyte haplotype and environmental factors on host growth and physiological parameters, we used Neotyphodium infected (E+) and uninfected (E-) Arizona fescue seeds from four naturally-infected maternal plants (MD 1, MD 44, MD 46, and MD 49) from the same population at Merritt Draw. Merritt Draw is a drainage meadow on the Mogollon Rim (elevation 2500 m) in Arizona. Maternal plants were randomly selected in 1997 from a pool of about 50 infected plants in the population. To remove the endophyte, maternal plants were split into ramets and half were treated hydroponically with low levels of the fungicide propiconazole while the other half were treated the same except without fungicide (Faeth \& Sullivan 2003). All ramets were planted individually into $16 \mathrm{oz}$ cups with native soil (Brolliar stony clay loam) and continually split and repotted as they grew for about 1 year to provide cloned replicates after hydroponic treatment. The clones were then transplanted to a plot at the Arboretum in Flagstaff in 1998. After growing for 3 years in the field, E+ and E- (endophyte experimentally removed) seeds from each of the four maternal plant genotypes used in this experiment were collected from the clones. Seeds were collected from E- and E+ plants in September 2001, cold-treated for 30 days at $5^{\circ} \mathrm{C}$ and then stored at room temperature. 
Table 1 Summary of ANOVA for the effects of plant genotype (nested within haplotype) and infection status on biomass and growth parameters (R:S = above-ground:below-ground biomass ratio; NAR = net assimilation rate; LAR = leaf area ratio; SLM = specific leaf mass).

\begin{tabular}{|c|c|c|c|c|c|c|c|c|c|c|}
\hline $\begin{array}{l}\text { Source of } \\
\text { variation }\end{array}$ & $d f$ & $\begin{array}{c}\text { Total } \\
\text { biomass }\end{array}$ & $\begin{array}{l}\text { Above- } \\
\text { ground } \\
\text { biomass }\end{array}$ & $\begin{array}{l}\text { Below- } \\
\text { ground } \\
\text { biomass }\end{array}$ & $R: S$ & RGR & $\begin{array}{c}\text { Total } \\
\text { leaf area }\end{array}$ & NAR & LAR & SLM \\
\hline \multirow{2}{*}{$\begin{array}{l}\text { Infection } \\
\text { Genotype } \\
\text { (Haplotype) }\end{array}$} & 1 & 0.837 & 0.170 & 0.264 & $<0.001$ & 0.172 & 0.066 & 0.348 & $<0.001$ & 0.386 \\
\hline & 2 & 0.073 & 0.497 & $<0.001$ & $<0.001$ & $<0.001$ & 0.453 & $<0.001$ & 0.406 & $<0.001$ \\
\hline $\begin{array}{l}\text { Infection x } \\
\text { Genotype } \\
\text { (Haplotype) }\end{array}$ & 2 & 0.693 & 0.303 & 0.056 & 0.001 & 0.010 & 0.819 & 0.984 & 0.658 & 0.002 \\
\hline Error & 195 & & & & & & & & & \\
\hline
\end{tabular}

Significant $(\mathrm{P}<0.05)$ effects are in bold.

Table 2 Summary of ANOVA of the effects of endophyte haplotype on biomass and growth parameters. (R:S = aboveground to below-ground biomass ratio; NAR = net assimilation rate; LAR = leaf area ratio; SLM = specific leaf mass). Only infected plants were included in these analyses.

\begin{tabular}{|c|c|c|c|c|c|c|c|c|c|c|}
\hline $\begin{array}{l}\text { Source of } \\
\text { variation }\end{array}$ & $d f$ & $\begin{array}{c}\text { Total } \\
\text { biomass }\end{array}$ & $\begin{array}{l}\text { Above- } \\
\text { ground } \\
\text { biomass }\end{array}$ & $\begin{array}{l}\text { Below- } \\
\text { ground } \\
\text { biomass }\end{array}$ & $R: S$ & RGR & $\begin{array}{c}\text { Total } \\
\text { leaf area }\end{array}$ & NAR & LAR & SLM \\
\hline Haplotype & 2 & 0.029 & 0.418 & 0.002 & 0.002 & $<0.001$ & 0.090 & $<0.001$ & 0.742 & 0.623 \\
\hline Error & 99 & & & & & & & & & \\
\hline
\end{tabular}

Significant $(\mathrm{P}<0.05)$ effects are in bold.

Table 3 Summary of ANOVA for the between-subject effects of plant genotype (nested within haplotypes), and infection status on leaf water potential $\left(\Psi_{\mathrm{L}}\right)$, leaf rolling, and stomatal density.

\begin{tabular}{lcccc}
\hline Source of variation & $\mathrm{df}$ & $\Psi_{\mathrm{L}}$ & Leaf rolling & Stomatal density \\
\hline Infection & 1 & $<\mathbf{0 . 0 0 1}$ & $\mathbf{0 . 0 0 3}$ & 0.308 \\
Genotype (Haplotype) & 2 & 0.184 & $<\mathbf{0 . 0 0 1}$ & $\mathbf{0 . 0 0 5}$ \\
Infection x Genotype (Haplotype) & 2 & 0.467 & 0.562 & 0.119 \\
Error & 195 & & \\
\hline
\end{tabular}

Significant $(\mathrm{P}<0.05)$ effects are in bold.

Table 4 Summary of ANOVA for the effects of endophyte haplotype on leaf water potential $\left(\Psi_{\mathrm{L}}\right)$, leaf rolling, and stomatal density. Only infected plants were included in these analyses.

\begin{tabular}{lcccc}
\hline Source of variation & $\mathrm{df}$ & $\Psi_{\mathrm{L}}$ & Leaf rolling & Stomatal density \\
\hline Haplotype & 2 & $<0.001$ & $<0.001$ & $<0.001$ \\
Error & 99 & & & \\
\hline
\end{tabular}

Significant $(\mathrm{P}<0.05)$ effects are in bold.

\section{The experiment}

Neotyphodium infected (E+) and uninfected (E-) Arizona fescue seeds from four infected maternal plants were planted in individual pots. To remove the endophyte, maternal plants were split into ramets and half were treated hydroponically with low levels of the fungicide propiconazole while the other half were treated the same except without fungicide (Faeth \& Sullivan 2003). Seeds of four genotypes of Arizona fescue, MD 1, MD 44, MD 46, MD 49 were sown in a 50:50 mix of native soil to potting soil (Super Soil, Supersoil and Rod McLellan Company,
San Mateo, CA, USA). Trays were placed in a growth chamber under a $22^{\circ} / 15^{\circ} \mathrm{C}$ (day/night) temperature regime with an $18 \mathrm{~h}$ photoperiod, during which time they received $400 \mu \mathrm{mol} / \mathrm{m}^{2} / \mathrm{s}$ photosynthetically active radiation (PAR) from a combination of cool white florescence tubes (F72T12/CW/VHO, Sylvania, Hart Lighting and Supply Inc., Phoenix, Arizona, USA) and incandescent bulbs (60 W XL, Sylvania, Hart Lighting and Supply Inc., Phoenix, Arizona, USA). Soils were watered to field capacity three times per week and seeds were allowed to germinate. After 21 days seedlings were transplanted from the 
Figure 1 Total (A), above-ground (B), below-ground (C) biomass, and below-ground biomass:above-ground biomass ratio $(D)$ of two endophyte haplotypes $(\mathrm{H} 1$ and $\mathrm{H} 2)$ of infected $(\mathrm{E}+)$ Arizona fescue. Different letters indicate means are significantly different $(\mathrm{P}<0.05)$. Only infected plants are included.

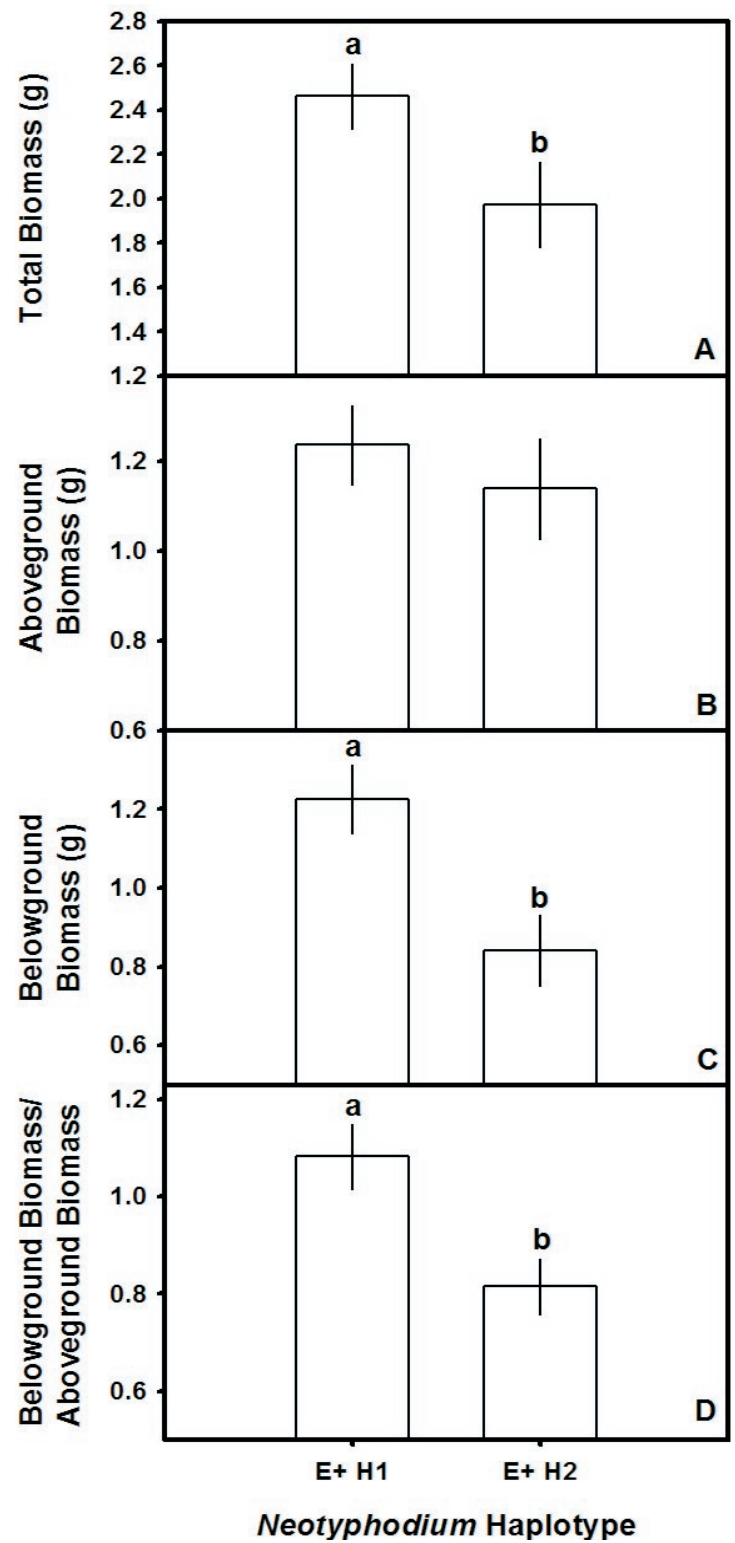

plastic trays into individual square pots $(11 \times 11 \times 11 \mathrm{~cm}, \mathrm{~L} \times$ W $\times \mathrm{H}$ ) containing the above native soil/potting soil mixture and allowed to establish for 21 days after which $12 \mathrm{E}+$ and 12 E- plants were randomly sacrificed for initial above-ground and below-ground biomass.

Plant infection status was confirmed using a modified tissue print immunoblot (Schulthess \& Faeth, 1998) at the start of the experiment. Twenty four E+ plants and $24 \mathrm{E}-$ plants were used from each maternal plant genotype in this experiment.

\section{Biomass production and growth}

The effect of endophyte infection on biomass production and growth parameters was determined over a 49 day period which began after the 21 st day of the establishment period. At the end of the period, plants were divided into roots and above-ground parts, and soil was washed from roots by hand. Specific leaf mass (SLM) was determined on a subsample of each plant (containing about $25 \%$ of the total leaves) using a leaf area meter (Decagon Devices, Pullman, WA, USA). Above-ground biomass was placed in an oven at $60^{\circ} \mathrm{C}$ for $24 \mathrm{~h}$ and below-ground biomass was placed in an oven at $105^{\circ} \mathrm{C}$ for $48 \mathrm{~h}$. Following this drying period above- and below-ground biomass was determined by weighing samples on a balance (Mettler Toledo, Inc., OH, USA). Biomass of E+ or E- plants at the initial harvest were randomly paired with respective $\mathrm{E}+$ or E- plants at the final harvest, and the relative growth rate (RGR; rate of biomass gain per biomass) and net assimilation rate (NAR; rate of biomass gain per leaf area) of each plant was estimated using the equations in Xiong et al. (2000), following Hunt (1990). Total leaf area was measured using a leaf area meter (Decagon Devices, Pullman, WA, USA). Leaf area ratio (LAR; leaf area per total plant biomass), leaf mass ratio (LMR; leaf biomass per total plant biomass), and belowground:above-ground biomass ratio (R:S) were also calculated.

\section{Water potential}

Leaf water potential $\left(\Psi_{\mathrm{L}}\right)$ was measured on the 42nd day following the start of the experiment using a pressure chamber (Model 1003, PMS, Corvallis, Oregon, USA) on one leaf from each plant. The leaf was cut $6 \mathrm{~cm}$ from its tip. Leaf water potential was only measured once per maternal plant genotype because $\Psi_{\mathrm{L}}$ does not vary much throughout consistent water treatments and remains relatively constant (Morse et al. 2002).

\section{Leaf rolling and stomatal density}

Leaf rolling and stomatal density were measured on the first day of the treatments and on the day before plants were harvested for comparison (data reported only for the last day). The width of one of the longest green leaves on each plant was measured $5 \mathrm{~cm}$ from the tip using a caliper holding the mid-vein in the center. This measurement was termed actual leaf width. The leaf was then excised $10 \mathrm{~cm}$ from the tip, forcibly unrolled, and the opened leaf width was measured $5 \mathrm{~cm}$ from the tip using a caliper and holding the mid-vein in the center. The ratio of actual leaf width to opened leaf width was termed leaf rolling. The same leaf was then used to measure stomatal density using the method of Kubinová (1994). Stomata are only present on the adaxial side of Arizona fescue leaves.

\section{Statistical analyses}

Separate analyses of variance (ANOVA) were used to examine the effect of infection (E+ or E-), maternal plant genotype effects on biomass production and growth parameters, $\Psi_{\mathrm{L}}$, leaf rolling, and stomatal density Plant maternal genotype was a nested factor within endophyte haplotype because each plant half-sib genotype was associated with only one of the two endophyte haplotypes. To assess the effect of endophyte haplotype on biomass production and growth parameters,, , leaf rolling, and stomatal density we conducted separate analyses of variance with only infected plants, because endophyte-removed plants obviously had no endophyte haplotype associated with them.

We also tested for differences in biomass measurements and physiological parameters among maternal plant genotypes when the endophyte was removed to provide an estimation of variation 
Figure 2 Relative growth rate (RGR; A), total leaf area (B), net assimilation rate (NAR; C), leaf area ratio (LAR; D), and specific leaf mass (SLM; E) of two endophyte haplotypes $(\mathrm{H} 1$ and $\mathrm{H} 2)$ of infected $(\mathrm{E}+)$ Arizona fescue. Different letters indicate means are significantly different $(P<0.05)$.

Only infected plants are included.

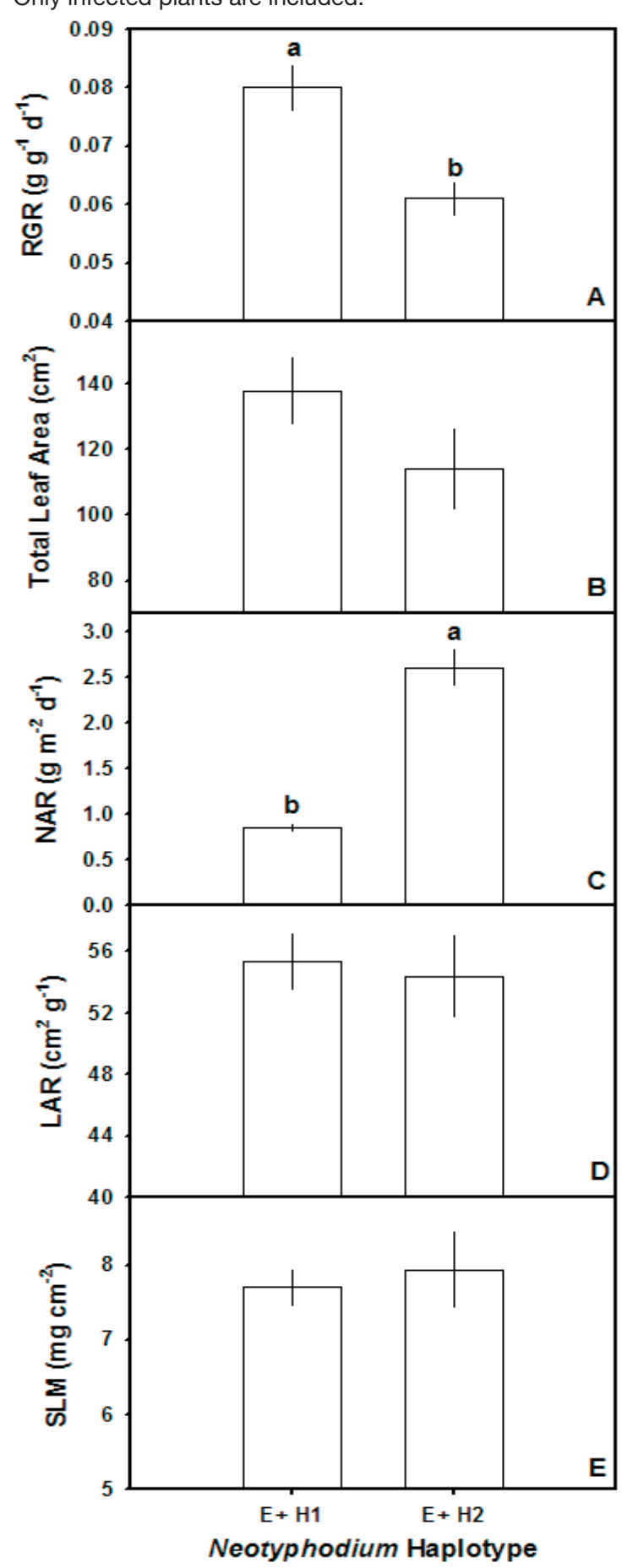

Neotyphodium Haplotype
Figure 3 Leaf water potential (A), actual leaf width: opened leaf width (B), and stomatal density $(\mathrm{C})$ of two endophyte haplotypes $(\mathrm{H} 1$ and $\mathrm{H} 2)$ of infected $(\mathrm{E}+)$ Arizona fescue. Different letters indicate means are significantly different $(\mathrm{P}<0.05)$.

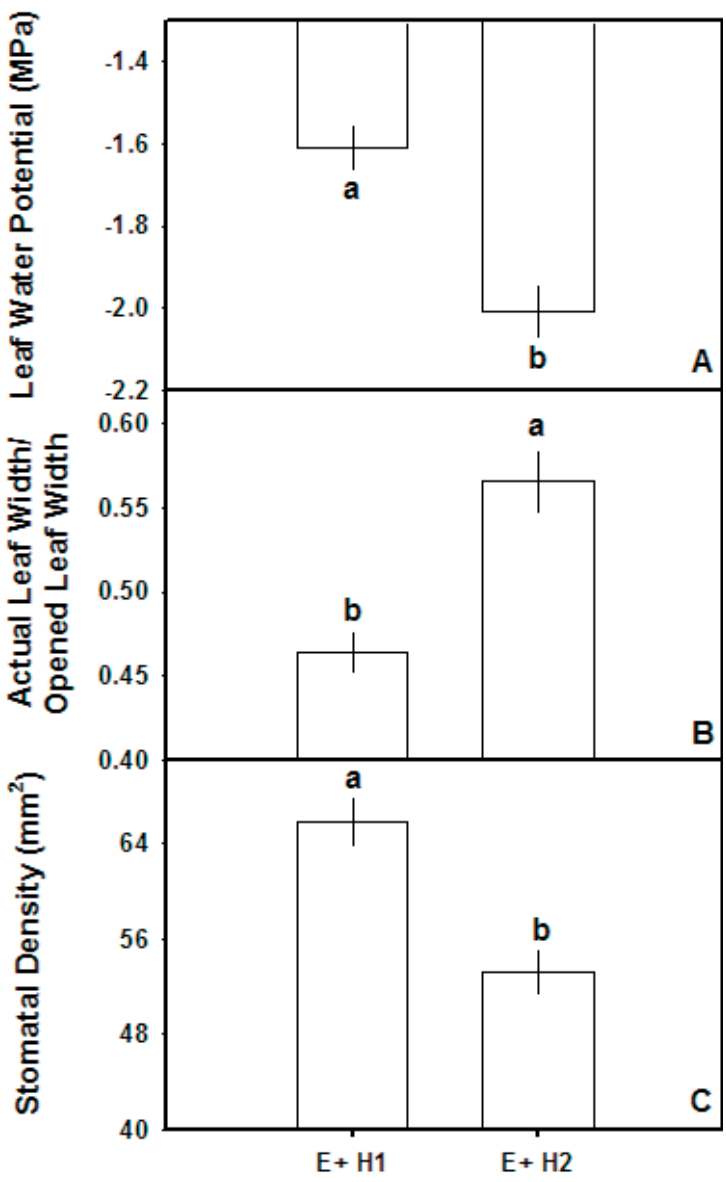

\section{Neotyphodium Haplotype}

due only to maternal plant genotype without the complicating factors of infection and endophyte haplotype. All data sets satisfied the assumptions of ANOVA based on homogeneity of variances, normality of errors, and independence of errors.

\section{Results}

\section{Biomass production and growth}

Endophyte haplotype affected total, below-ground biomass and below-ground biomass:above-ground biomass (Table 1, Fig. 1). Furthermore, relative growth rates and net assimilation rate (NAR) differed significantly between the two endophyte haplotypes (Table 2, Fig. 2). In general, plants harbuoring the $\mathrm{H} 1$ endophyte haplotype had greater biomass (Fig. 1), net assimilation rate and relative growth rates (Fig. 2) than plants harbouring the $\mathrm{H} 2$ endophyte haplotype. Plants infected with the $\mathrm{H} 1$ haplotype had greater total leaf area than plants with the $\mathrm{H} 2$ haplotype, but this difference was only marginally different $(\mathrm{P}$ $=0.09$, Fig. 2B). There was a significant endophyte haplotype effect within plant maternal genotype on below-ground biomass, below-ground biomass/above-ground biomass, NAR, and SLM. 
Leaf water potential, leaf rolling, and stomatal density

The presence of Neotyphodium also affected leaf water potential $\left(\Psi_{\mathrm{L}}\right)$ (Table 3). Neotyphodium infected plants had less negative $\Psi_{\mathrm{L}}$ than plants with their endophytes removed. Leaf rolling, but not stomatal density, also varied with infection (Table 3). E+ plants showed greater leaf rolling (a lower actual leaf width:opened leaf width ratio) than E- plants.

The two Neotyphodium haplotypes also differed in leaf water potential. Infected plants with the $\mathrm{H} 2$ haplotypes had more negative $\Psi_{\mathrm{L}}$ than $\mathrm{H} 1$ plants (Table 4, Fig. 3A). Leaf rolling and stomatal density also varied with endophyte haplotypes (Table 4, Fig. 3 B,C). Plants harbouring the $\mathrm{H} 1$ endophyte rolled leaves more tightly than $\mathrm{H} 2$ plants (Fig. 3B), and $\mathrm{H} 1$ plants had higher stomatal density than $\mathrm{H} 2$ plants (Fig. 3C). There were no significant endophyte effects within maternal genotype (data not shown).

\section{Discussion}

In native Arizona fescue, haplotype of the endophyte is the most critical and consistent factor influencing the growth and biomass production of Arizona fescue plants, as well as physiological outcomes such as leaf water potential, leaf rolling, and stomatal density. Endophyte haplotype appears to override infection status, at least in determining growth and some physiological measures. Within infected plants, the strain of endophyte, even within the same population, greatly influences relative performance and physiological aspects of the host plant. In addition, the many complex interactions involving plant maternal genotype and endophyte haplotype, and endophyte infection indicate that the direction and magnitude of Neotyphodium interactions with this native host grass, even under laboratory conditions, are highly variable and complex.

Genetic background of the maternal host plants results in additional variation in below-ground biomass accumulation, and allocation to roots and shoots, as indicated by differences among maternal host plant genotypes that are without their endophytes. Host plant genetic variation, even in cultivated grasses, where host genetic variation is reduced relative to wild grasses because of cultivation and selective breeding, can also result in different growth and reproductive performance (e.g. Cheplick \& Cho 2003).

\section{Physiological and morphological variation}

Consistent with previous physiological studies of Neotyphodium infection in Arizona fescue (Morse et al. 2002; Morse 2005), $\Psi_{\mathrm{L}}$ was less negative in $\mathrm{E}+$ plants than E- plants and infected plants with $\mathrm{H} 1$ endophytes had less negative $\Psi_{\mathrm{L}}$ than plant with $\mathrm{H} 2$ endophytes. E+ plants also had more tightly rolled leaves than E- plants regardless of treatment. Rolling leaves more tightly may be the reason for $\mathrm{E}+$ plants maintaining less negative $\Psi$ than E- plants. Leaf movements, such as rolling, are common adaptive mechanisms to water stress and drought conditions in plants. These movements help in reducing incident irradiation, leaf temperature, and transpiration (Begg 1980; Ehleringer \& Forseth $1980)$ by decreasing the exposed leaf area and leaf conductance to water vapour $\left(g_{s}\right)$ (Begg 1980), although the effect of leaf rolling on transpiration is dependent on stomatal distribution and on the degree and pattern of stomatal opening in rolled leaves. Rolling prevents water loss but also restricts potential carbon gain and may place the plant at a competitive disadvantage especially if adequate soil water is available. Infected plants tended to produce less above-ground biomass than E- plants regardless of maternal genotype. Likewise, within infected plants, $\mathrm{H} 1$ plants rolled leaves more tightly than $\mathrm{H} 2$ plants, and also had less negative $\Psi_{\mathrm{L}}$ than $\mathrm{H} 2$ plants, further supporting the link between increased leaf rolling and less negative $\Psi_{L}$. Endophyte haplotype also affected stomatal density indicating that endophyte haplotypes create additional variation in the host plant response to environmental variation.

The effect of endophyte infection, plant maternal genotype and endophyte haplotype on stomatal density may be a result of gibberellic acid produced by the endophyte, which is the primary hormone involved in stomata formation (Saibo et al. 2003). Little is known about the biochemical mechanisms that alter growth and increase stress tolerance in Neotyphodium infected plants. De Battista et al. (1990) and Yue et al. (2001) suggested that auxin (indoleacetic acid; IAA) may play a role in plant growth alterations in infected plants. Joost et al. (1993) showed experimentally that endophyte infection altered the physiology of infected plants via hormonal signals, such as abscisic acid, that promote guard cell closure, although one should note that these results have not been replicated. Apparently, endophyte strain also influences levels of plant hormones, as suggested by differences in stomatal density between $\mathrm{H} 1$ and $\mathrm{H} 2$ endophyte-infected plants. Further research into the area of plant-endophyte interactions at the physiological level could help to elucidate endophyte infection and haplotype effects across different Arizona fescue genotypes.

Our general findings show that Neotyphodium haplotype, and to a lesser extent Neotyphodium infection and host plant maternal genotype, influence Arizona fescue growth and biomass production. Therefore, it is likely that these factors also influence other interactions with the host grass, such as susceptibility to herbivory and pathogens, inter- and intraspecific competition, and community structure. Neotyphodium infections in tall fescue can modify diversity-productivity relationships by increasing the level of competition between non-tall fescue species and tall fescue (Rudgers et al. 2004) and alter community and ecosystem properties in old fields (Matthews \& Clay 2001; Clay \& Holah 1999; Clay et al. 2005). Further, Omacini et al. (2001) showed that fungal endophyte infection in Lolium multiflorum (Italian ryegrass), an agronomic grass, alters food-web structure by disrupting the transfer of energy from plants to upper trophic levels. Extrapolating from agronomic grass studies to natural populations and communities may be far too simplistic, given that agronomic grasses and their endophytes typically have much less genetic diversity due to selective breeding and genetic bottlenecks (Saikkonen et al. 2004) and are grown in environments that are less variable than natural populations. With the greater genetic diversity in both the endophyte (e.g. Faeth \& Sullivan 2003) and its grass host (e.g. Saikkonen et al. 2004) natural populations should exhibit much greater complexities. Based upon our results that endophyte haplotype, plant maternal genotype and environmental factors, in addition to infection, result in highly variable outcomes in terms of host performance and physiology, we conclude it will be extraordinarily difficult to predict effects at the population, community and ecosystem levels.

\section{ACKNOWLEDGMENTS}

T. Bender, C. Hayes, A. Jani, R. Overson, S. Strauss, T.J. Sullivan, S. Wittlinger NSF grants DEB 9727020 and 0128343

\section{REFERENCES}

Assuero, S.G.; Matthew, C.; Kemp, P.D.; Barker, D.J.; Mazzanti, A. 2002. Effects of water deficit on Mediterranean and temperate cultivars of tall fescue. New Zealand Journal of Agricultural Research 53: 29-40.

Begg, J.E. 1980. Morphological adaptations of leaves to water stress. In: Adaptations of Plants to Water and High 
Temperature Stress. Eds N.C. Turner \& P.J. Kramer, Wiley Interscience, New York, NY.

Cheplick, G.P.; Cho, R. 2003. Interactive effects of fungal endophyte infection and host genotype on growth and storage in Lolium perenne. New Phytologist 158: 183-191.

Clay, K.; Holah, J. 1999. Fungal endophyte symbiosis and plant diversity in successional fields. Science 285: 1742-1744.

Clay, K.; Holah, J.; Rudgers, J.A. 2005. Herbivores cause a rapid increase in hereditary symbiosis and alter plant community composition. Proceedings of the National Academy of Science 102: 12465-12470.

de Battista, J.P.; Bouton, J.H.; Bacon, C.W.; Siegel, M.R. 1990. Rhizome and herbage production of endophyte-removed tall fescue clones and populations. Agronomy Journal 82: 651-654.

Ehleringer, J.; Forseth, I. 1980. Solar tracking of plants. Science 210: 1094-1098.

Faeth, S.H. 2002. Are endophytic fungi defensive plant mutualists? Okios 98: 25

Faeth, S.H.; Sullivan, T.J. 2003. Mutualistic asexual endophytes in a native grass are usually parasitic. American Naturalist 161: 310-325.

Hunt, R. 1990. Basic Growth Analysis. Unwin Hyman Limited, London, UK.

Joost, R.E., Sharp, R.E. \& Holder, T.L. (1993) Involvement of the Acremonium endophyte in ABA-mediated gas exchange responses in tall fescue. pp. 41-42. In: Proceedings of the Tall Fescue Toxicosis Warshop, Atlanta, GA. SERAIEG-8.

Kearney, T.H.; Peebles, R.H. 1960. Arizona Flora. University of California Press, Berkeley.

Kubínová, L. 1994. Recent stereological methods for measuring leaf anatomical characteristics: estimation of the number and sizes of stomata and mesophyll cells. Journal of Experimental Botany 45: 119-127.

Matthews J.W.; Clay, K. 2001. Influence of fungal endophyte infection on plant-soil feedback and community interactions. Ecology 82: 500-509.

Morse, L.J. 2005. The physiological role of the Neotyphodium endophyte in Festuca arizonica. Ph.D. Dissertation. Arizona State University, Tempe, A.Z., USA.

Morse, L.J.; Day, T.A.; Faeth, S.H. 2002. Effect of Neotyphodium endophyte infection on growth and leaf gas exchange of Arizona fescue under contrasting water availability.
Environmental and Experimental Botany 48: 257-268.

Müller, C.B.; Krauss, J. 2005. Symbiosis between grasses and asexual endophytes. Current Opinion in Plant Biology 8: 450-456.

Omacini, M.; Chaneton, E.J.; Ghersa, C.M.; Müller, C.B. 2001. Symbiotic fungal endophytes control insect host-parasite interaction webs. Nature 409: 78-81

Rudgers, J.A.; Koslow, J.M.; Clay, K. 2004. Endophytic fungi alter relationships between diversity and ecosystems properties. Ecology Letters 7: 42-51.

Saibo, N.J.M.; Vriezen, W.H.; Beemster, G.T.S.; Van Der Straeten, D. 2003. Growth and stomata development of Arabidopsis hypocotyls are controlled by gibberellins and modulated by ethylene and auxins. The Plant Journal 33: 989-1000.

Saikkonen, K.; Helander, M.; Faeth, S.H.; Schulthess, F.;Wilson, D. 1999

Endophyte-grass-herbivore interactions: the case of Neotyphodium endophytes in Arizona fescue populations. Oecologia 121: 411-420.

Saikkonen, K.; Wali, P.; Helander, M.; Faeth, S.H. 2004. Evolution of endophyte-plant symbioses. Trends in Plant Science 9: 275-280.

Schulthess, F.M.; Faeth, S.H. 1998. Distribution, abundances, and associations of the endophytic fungal community of Arizona fescue (Festuca arizonica). Mycologia 90: 569-578.

Sullivan, T.J. 2003. Geographic and genetic variation in the Neotyphodium/Festuca arizonica interaction. $\mathrm{PhD}$ Dissertation. Arizona State University.

Sullivan, T.J.; Faeth, S.H. 2004. Gene flow in the endophyte Neotyphodium and implications for coevolution with Festuca arizonica. Molecular Ecology 13: 649-656.

Wilkinson, H.H.; Schardl, C.L. 1997. The evolution of mutualism in grass-endophyte associations. pp. 13-26 In: Neotyphodium/ Grass Interactions. Eds C.W. Bacon \& N.S. Hill, Plenum Press, New York.

Xiong, F.S.; Mueller, E.C.; Day, T.A. 2000. Photosynthetic and respiratory acclimation and growth response of Antarctic vascular plants to contrasting temperature regimes. American Journal of Botany 87: 700-710.

Yue, Q.; Wang, C.; Gianfagna, T.J.; Meyer, W.A. 2001. Volatile compounds of endophyte-free and infected tall fescue (Festuca arundinacea Schreb.). Phytochemistry 58: 935-941. 